\title{
MECHANIKAL APPLICATIONS OF THE HARMLESS ERROR RULE IN CASES OF PROSECUTORIAL GRAND JURY MISCONDUCT
}

\section{INTRODUCTION}

The fifth amendment provides that "[n]o person shall be held to answer for a capital, or otherwise infamous crime, unless on a presentment or indictment of a Grand Jury."1 This constitutional guarantee derives from the traditional English institution of the grand jury, which English settlers brought to the American colonies. ${ }^{2}$ Originally used to aid the Crown in detecting and prosecuting crimes, the English grand jury came to be perceived as a shield for the accused against baseless accusations. ${ }^{3}$ Thus, in the American colonies, the grand jury often thwarted the Crown's efforts to enforce unpopular laws and to prosecute those challenging its authority. ${ }^{4}$ Against this background, the Framers incorporated the requirement of indictment by grand jury into the Bill of Rights. As the Supreme Court has noted, the transplanted English institution theoretically serves "as a means, not only of bringing to trial persons accused of public offences upon just grounds, but also as a means of pro-

1. U.S. CONST. amend. V. Cases "arising in the land or naval forces, or in the Militia, when in actual service in time of War or public danger" are excepted from the requirement. Id.

2. Costello v. United States, 350 U.S. 359, 362 (1956); 1 S. Beale \& W. BRYson, Grand JURY LAW AND Practice $§ 1: 03$, at 12 (1986). For a concise and thorough treatment of the historical development of the American grand jury, see id. $\S$ 1:01-:06, and M. FRANKEL \& G. NAFTALIS, The GRand JuRY 6-17 (1977).

3. I S. BEAle \& W. BRYSON, supra note 2, § 1:02, at 7-9; M. FranKel \& G. NAFTaLIS, supra note 2, at 9-10. As one writer of the period remarked, the grand jury's function had become

[t]o preserve the Innocent from the Disgrace and Hazards which ill Men may design to bring them to, out of Malice, or through Subornation, or other sinister Ends; for so tender is the Law, of the Reputation and Life of a Man, that it will not suffer the one to be sullied

$\ldots$ and the other indangered by a Trial, until first the Matter and Evidence against him have been scann'd, examined, and found by a Grand Jury, upon their Oaths, against him.

H. Care, English Liberties, or the Free-Born SUbJect's INHeritance 252 (4th ed. 1719), quoted in $1 \mathrm{~S}$. BEALE \& W. BRYSON, supra note $2, \S 1: 02$, at 9.

4. 1 S. BEALE \& W. BRYSON, supra note 2, § 1:03, at 13 (noting refusal to indict "for crimes involving resistance to British authority"); M. FRANKEL \& G. NAFTALIS, supra note 2, at 11-12 (noting refusal to indict either leaders of riot against Stamp Act or publisher who criticized colony's governor); Vaira, The Role of the Prosecutor Inside the Grand Jury Room: Where Is the Foul Line?, 75 J. Crim. L. \& Criminolocy 1, 1 (1984). 
tecting the citizen against unfounded accusation, whether it comes from government, or be prompted by partisan passion or private enmity."s

The American grand jury is thought to act as an independent entity, free from both judicial and executive control. ${ }^{6}$ Respect for this independence, and also for the traditional secrecy of grand jury proceedings, has restricted the scope of federal judicial review of such proceedings. ${ }^{7}$ The Court has stated that the American grand jury, like its English antecedent, is "not [to be] hampered by rigid procedural or evidential rules."8 Moreover, excessive judicial supervision of prosecutorial conduct before the grand jury could infringe executive branch prerogatives, creating separation of powers problems. ${ }^{9}$ Courts have therefore hesitated to review prosecutors' actions before grand juries. This institutional restraint, coupled with the prosecutors' dominant role in grand jury proceedings, creates an environment susceptible to prosecutorial overreaching.

Prosecutors effectively control grand jury proceedings by selecting the matters and individuals under investigation, directing the interrogation of witnesses, serving as legal advisor to the process, and drafting indictments for the grand jury's imprimatur. ${ }^{10}$ Moreover, individuals who appear before a grand jury have no right to the presence of counsel

5. Ex parte Bain, 121 U.S. 1, 11 (1887), quoted with approval in Stirone v. United States, 361 U.S. 212, 218 n.3 (1960); see also Wood v. Georgia, 370 U.S. 375, 390 (1962):

Historically, this body has been regarded as a primary security to the innocent against hasty, malicious and oppressive persecution; it serves the invaluable function in our society of standing between the accuser and the accused .... to determine whether a charge is founded upon reason or was dictated by an intimidating power or by malice and personal ill will.

6. See, e.g., Stirone, 361 U.S. at 218 ("The very purpose of the requirement that a man be indicted by grand jury is to limit his jeopardy to offenses charged by a group of his fellow citizens acting independently of either prosecuting attorney or judge." (emphasis added)); Costello, 350 U.S. at 362; United States v. Chanen, 549 F.2d 1306, 1312 (9th Cir.), cert. denied, 434 U.S. 825 (1977); see also 2 S. BEALE \& W. BRYSON, supra note $2, \S 10: 18$ (scope of judicial review of grand jury proceedings restricted in light of traditional independence of grand jury); 1 id. $\$ 1: 04$ (historical view).

7. See generally 2 S. BEALE \& W. BRYSON, supra note $2, \S 10: 18$ (discussing judicial review of grand jury proceedings).

8. Costello, 350 U.S. at 362; see also Blair v. United States, 250 U.S. 273, 282 (1919) ("the scope of [the grand jury's] inquiries is not to be limited narrowly by questions of propriety").

9. See United States v. Kilpatrick, 821 F.2d 1456, 1465 (10th Cir. 1987), aff'd sub nom. Bank of Nova Scotia v. United States, 108 S. Ct. 2369 (1988); United States v. De Rosa, 783 F.2d 1401, 1404 (9th Cir.), cert. denied, 477 U.S. 908 (1986); United States v. McClintock, 748 F.2d 1278, 1283 (9th Cir. 1984), cert. denied, 474 U.S. 822 (1985); see also 2 S. BEALE \& W. BRYSON, supra note 2, $\S 10: 18$ (separation of powers limits judicial authority to supervise prosecutors' conduct).

Courts' unwillingness to interfere with the grand jury's investigative and law enforcement functions also tends to restrict the scope of review of prosecutors' conduct. Id. $\S 10: 18$, at 63 (citing United States v. Calandra, 414 U.S. 338, 350 (1974)). This concern arises primarily in appeals filed during an ongoing grand jury proceeding. Id.

10. M. Frankel \& G. Naftalis, supra note 2, at 2; B. Gershman, Prosecutorial MisCoNDucr § 2.1, at 2-2 (1987); Note, The Exercise of Supervisory Powers to Dismiss a Grand Jury Indictment-A Basis for Curbing Prosecutorial Misconduct, 45 OHı ST. L.J. 1077, 1079 (1984). 
during their interrogation. ${ }^{11}$ This situation gives prosecutors considerable opportunity to abuse the grand jury process. ${ }^{12}$

The range of potential abuse matches the breadth of prosecutors' powers. ${ }^{13}$ Possible acts of prosecutorial misconduct include making inflammatory or prejudicial remarks about the accused, ${ }^{14}$ stating personal views in order to undermine the grand jury's independence, ${ }^{15}$ testifying before the grand jury, ${ }^{16}$ interfering with the grand jury's deliberations or voting, ${ }^{17}$ and knowingly presenting false or perjured evidence or failmg to take corrective measures after discovering the falsity of evidence. ${ }^{18}$

11. 1 S. BeAle \& W. BRYSon, supra note $2, \S 6: 16$, at 88 . Witnesses, however, may periodically consult with counsel outside the grand jury room. Id. They may also assert some evidentiary privileges. Id. $\S \S 6: 21$, at 128 (spousal, marital-communication, doctor-patient, and clergyman-communicant privileges), 6:22, at 132 (privilege against self-incrimination), 6:23, at 141 (attorney-client privilege).

12. As Judge Learned Hand remarked in his dissent in United States v. Remington, 208 F.2d 567 (2d Cir. 1953), cert. denied, 347 U.S. 913 (1954), "[s]ave for torture, it would be hard to find a more effective tool of tyranny than the power of unlimited and unchecked ex parte examination." Id. at 573 (L. Hand, J., dissenting); see also B. GERSHMAN, supra note 10, § 2.1, at 2-3, § 2.3, at 212. Of course, the grand jurors themselves provide an inherent check against the most extreme forms of prosecutorial misconduct; they can always, by returning a "no bill," refuse to indict.

13. See generally 2 S. BEALE \& W. BRYSON, supra note 2, $\S \S 10: 01-12$ (discussing various forms of misconduct); B. Gershman, supra note 10, $\S$ 2.3-.4, 2.6-.9 (same); Note, Prosecutorial Misconduct in the Grand Jury: Dismissal of Indictments Pursuant to the Federal Supervisory Power, 56 FoRDHAM L. REv. 129, 134-35 (1987) (citing and discussing types of misconduct); Note, supra note 10, at 1081 n. 36 (cataloguing misconduct and illustrative cases).

As used in this Note, the term "prosecutorial grand jury misconduct" refers to acts by a prosecutor that violate a judge-made or statutory rule designed to protect the integrity and independence of grand juries.

14. See, e.g., United States v. Hogan, 712 F.2d 757, 761 (2d Cir. 1983) (prosecutor presented speculative hearsay about defendant's involvement in murders not under investigation by grand jury); United States v. DiGregorio, 605 F.2d 1184, 1189 (1st Cir.) (prosecutor intimidated witness and insinuated that targets of investigation would harm witness), cert. denied, 444 U.S. 937, 444 U.S. 944, 444 U.S. 983 (1979); United States v. Serubo, 604 F.2d 807, 814-17 (3d Cir. 1979) (prosecutor commented on veracity of witnesses and alleged, without foundation, that defendant had links to organized crime).

15. See, e.g., United States v. McKenzie, 678 F.2d 629, 632 (5th Cir.) (prosecutor expressed opinions on witness credibility and told grand jurors that all prosecutors signed indictment because prosecutors felt it was warranted), cert. denied, 459 U.S. 1038 (1982).

16. See, e.g., United States v. Treadway, 445 F. Supp. 959, $963-64$ (N.D. Tex. 1978) (prosecutor testified before grand jury).

17. See, e.g., United States v. Wells, 163 F. 313, 314-15 (D. Idaho 1908) (district attorney commented on evidence, explained law, and applied it to facts during grand jury deliberations).

18. See, e.g., United States v. Hogan, 712 F.2d 757, 761-62 (2d Cir. 1983) (false testimony by DEA agents); United States v. Basurto, 497 F.2d 781, 785 (9th Cir. 1974) (prosecutor, learning that witness perjured testimony, informed opposing counsel but not court or grand jury).

Prosecutors also use the grand jury for such improper purposes as collecting evidence for civil investigations or pending criminal prosecutions, or harrassing individuals or groups. See $2 \mathrm{~S}$. BEALE \& W. BRYSON, supra note 2, $\S \S 10: 13-: 17$; see also M. Frankel \& G. NAFTALIS, supra note 2, at 52.59 (expressing concern with use of grand jury to oppress radical and nonconformist groups and invade witnesses' first amendment rights). These abuses, however, do not affect grand juries' indictment decisions, the focal point of this Note. 
Misconduct might also involve violations of procedural rules designed to protect both the target and the general integrity of the deliberative process. ${ }^{19}$

Over the years, some federal appellate courts, in an effort to redress or deter flagrant prosecutorial misconduct before grand juries, have dismissed indictments even after a defendant's conviction. ${ }^{20}$ Now, however, if a defendant moves for such a dismissal and a district court denies the defendant's motion or takes it under advisement, a petit jury's guilty verdict may insulate the district court's ruling from meaningful appellate review; under the Supreme Court's decision in United States $v$. Mechanik, ${ }^{21}$ a verdict of guilty confirms a grand jury's finding of probable cause to indict.

In Mechanik, the Supreme Court held that a gnilty verdict mooted the question whether a grand jury indictment that resulted from simultaneous testimony of two government witnesses-a clear violation of Federal Rule of Criminal Procedure 6(d)-was tainted.22 The Court reasoned that although the presence of more than one witness might have influenced the grand jury's decision to indict, the trial jury's guilty verdict removed any doubt about the existence of probable cause. ${ }^{23}$ The guilty verdict thus rendered harmless any error resulting from the trial court's failure to dismiss the indictment because of the Rule 6(d) violation. ${ }^{24}$

In the aftermath of Mechanik, appellate courts have generally dismissed postconviction appeals that allege prosecutorial inisconduct in

19. See, e.g., Bank of Nova Scotia v. United States, 108 S. Ct. 2369, 2375 (1988) (misconduct included violations of Rules 6(d) (unauthorized person in grand jury room) and 6(e) (secrecy of proceedings)).

20. E.g., Hogan, 712 F.2d at 761-62 (dismissal warranted where prosecutor presented extensive hearsay and depicted accused as "hoodlum" who should be indicted as a "matter of equity"); see $2 \mathrm{~S}$. BEALE \& W. BRYSON, supra note 2, $\S \S 10: 22$, at 88-93, 10:23, at 103.

21. 475 U.S. $66,72-73$ (1986).

22. Id. at 70. Rule $6(d)$ provides:

Who MAY Be PRESENT. Attorneys for the government, the witness under examination, interpreters when needed and, for the purpose of taking the evidence, a stenographer or operator of a recording device may be present while the grand jury is in session, but no person other than the jurors may be present while the grand jury is deliberating or voting.

FED. R. CRIM. P. 6(d).

23. Mechanik, 475 U.S. at 70-71.

24. Id. at 73. Before Mechanik, courts often held that anything more than a fleeting "unauthorized presence" required automatic dismissal. See 2 W. LAFAve \& J. IsRaEl, Criminal ProCEDURE § 15.6, at 332 (1984). The Supreme Court saw "no reason" not to subject grand jury violations to harmless error analysis under FED. R. CRIM. P. 52(a), which provides: "Any error, defect, irregularity or variance which does not affect substantial rights shall be disregarded." Mechanik, 475 U.S. at 70. 
grand jury proceedings. ${ }^{25}$ Mechanik's harmless error analysis is troubling to some, however, because it may msulate prosecutorial misconduct before grand juries from postconviction appellate review. ${ }^{26}$ This prospect of unreviewability has prompted some courts (at least in dicta) to interpret the Supreme Court's holding narrowly. ${ }^{27}$ The issue has also attracted congressional attention. ${ }^{28}$ In addition, the Mechanik decision has

25. Dismissed appeals of this type have included United States v. Friedman, 854 F.2d 535, 58283 (2d Cir. 1988) (Rule 6(e) violation), petition for cert. filed sub nom. Lazar v. United States, 57 U.S.L.W. 3154 (U.S. Aug. 10, 1988) (No. 88-250); Umited States v. Hefner, 842 F.2d 731, 732-33 (4th Cir. 1988) (grand jury foreman not qualified to serve); United States v. Bucci, 839 F.2d 825, $831-32$ (1st Cir.) (appeal on grounds of prosecutor's failure to impeach allegedly perjured testimony or to present exculpatory evidence; inflaming of grand jury by suggesting that irrelevant, noncriminal conduct was wrongful), cert. denied, 109 S. Ct. 117 (1988); United States v. Fountain, 840 F.2d 509, 514-15 (7th Cir.) (failing to present exculpatory evidence and misleading grand jury about weight of evidence), cert. denied, 109 S. Ct. 533 (1988); United States v. Tobias, 836 F.2d 449, 452 (9th Cir. 1988) (denial of request for grand jury records for purposes of verifying whether grand jury was properly constituted and whether quorum existed); United States v. McKie, 831 F.2d 819, 82021 (8th Cir. 1987) (improper reference to previous convictions); United States v. Kouba, 822 F.2d 768, 773-74 (8th Cir. 1987) (misleading summaries of testimony; calling witnesses in order to have them invoke fifth amendment before grand jury; misconduct of government agent in connection with grand jury investigation); United States v. Hintzman, 806 F.2d 840, 843 (8th Cir. 1986) (hearsay evidence misleadingly presented; biased witness); Porter v. Wainwright, 805 F.2d 930, $941-42$ (11th Cir. 1986) (grand juror related to victim of alleged crime; prosecutor failed to disclose relationship), cert. denied, 107 S. Ct. 3195, 3196 (1987); United States v. Thomas, 788 F.2d 1250, 1254 (7th Cir.) (improper questions; failure to present exculpatory evidence; generally misleading and improperly advising grand jury), cert. denied, 479 U.S. 853 (1986).

26. See Arkin, Mechanik-A Year Later, N.Y.L.J., Apr. 9, 1987, at 1, col. 1; Curran \& Margolius, Many Remedies Exist to Address Prosecutorial-Misconduct Claims, Nat'1 L.J., Apr. 13, 1987, at 28, col. 1 .

27. See, e.g., United States v. Johns, 858 F.2d 154, 159-60 (3d Cir. 1988) (harmless error analysis inapplicable where issue is violation of right to fundamental fairness); United States v. Midland Asphalt Corp., 840 F.2d 1040, 1045-46 (2d Cir.) (error involving Rule 6(e) violation will not be rendered harmless by conviction under Mechanik), cert. granted, 108 S. Ct. 2869 (1988) (No. 871905); United States v. Taylor, 798 F.2d 1337, 1340 (10th Cir. 1986) (same); cf. United States v. LaRouche Campaign, 829 F.2d 250, 253 (1st Cir. 1987) (some error involving extremely egregious nisconduct night escape harmless error analysis).

28. Legislation to specifically overrule Mechanik was introduced in the 99th and 100th Congresses, E.g., H.R. 3308, 100th Cong., 1st Sess., introduced, 133 CoNG. REC. H7735 (daily ed. Sept. $21,1987)$ [hereinafter H.R. 100-3308]. The bill would have created the following new 18 U.S.C. §3322:

(a) GROUNDS FOR DISMISSAL. - The court shall dismiss an indictment if the court finds a substantial failure to comply with the law governing the grand jury proceedings out of which such indictment arose.

(b) IVhen Motion MAY be MAde; Effect of INTERVening Verdict.-A motion made under this section may be made at any time before, or, for good cause shown during, or after, trial. A verdict of guilty at trial does not affect the availability or determination of such motion.

H.R. 100-3308, supra, sec. 2(a), 3322(a)-(b).

Proponents of the bill characterized Mechanik as "an open invitation for prosecutors to disregard grand jury procedures" that undermines Congress's authority to enact rules for the federal courts because it "permit[s] prosecutors to violate these rules with no fear of enforceable sanctions." Grand Jury Reform: Hearings on H.R. 1407 and Related Bills Before the Subcomm. on Criminal Justice of the House Comm. on the Judiciary, 99th Cong., 1st \& 2d Sess. 309-10 (1986) [hereinafter 
raised the question whether defendants nay bring interlocutory appeals for denials of their motions to dismiss. ${ }^{29}$

This Note evaluates the judicial approaches to prosecutorial grand jury misconduct that have developed following the Suprenie Court's decision. First, the Note discusses Mechanik itself. It then considers in part II whether the decision's harmless error analysis justifies interlocutory review of alleged prosecutorial misconduct. In part III, the Note discusses the broader implications of Mechanik's holding for the appellate courts' role in supervisnig prosecutorial conduct before federal grand juries. The Note concludes that a fair reading of Mechanik virtually eliminates appellate review of prosecutorial misconduct that affects grand jury charging decisions. The historically strict application of the final judgment rule in cases of interlocutory criminal appeals allows no pre-judginent review of a prosecutor's actions, and the rationale of Mechanik, especially in light of other recent decisions, prevents circumvention of the harmless error rule in postconviction appeals.

\section{UNITED STATES V. MECHANIK}

The lower Mechanik courts focused on the question whether, to secure dismissal of an indictment that mvolves a Rule 6(d) violation, a

Hearings on H.R. 1407] (remarks of Rep. Edwards). Originally proposed as H.R. 5367, 99th Cong., 2d Sess., introduced, 132 CoNG. REc. H5773 (daily ed. Aug. 8, 1986), the measure was not enacted during the 99th Congress. It was introduced in March 1987 as H.R. 1348, 100th Cong., 1st Sess., introduced, 133 CoNG. Rec. H934 (daily ed. Mar. 3, 1987), and remtroduced with minor changes on September 21, 1987, as H.R. 100-3308, supra, see 133 CoNG. REC. H7735 (daily ed. Sept. 21, 1987). H.R. 100-3308 was referred to the House Committee on the Judiciary, where it died at the end of the 100th Congress.

Testimony at the hearings on the 1986 bill focused on the need to preserve the integrity of the grand jury process, rather than on the rights of individual defendants. See Hearings on H.R. 1407, supra, at 316 (statement of Bernard S. Bailor, Vice-Chairperson, ABA White Collar Crime Committee); id. at 336 (testimony of Henry Scott Wallace, Legislative Director, National Association of Criminal Defense Lawyers). As Mr. Wallace stated:

The question that confronts this subcommittee in this legislation is not whether . . . a defendant should be rewarded for having become the victim of some lapse before the grand jury, but whether the grand jury should have the continuing benefit of [the] protections that are contained in [Federal Rule of Criminal Procedure] 6 and perhaps those contained in the Constitution as well.

Id. Had Congress enacted the bill, it would have implicitly rejected the balance of interests strnck by Justice Rehnquist in his Mechanik opinion. See infra notes $42-44$ and accompanying text.

29. See, e.g., United States v. Poindexter, 859 F.2d 216, 218-22 (D.C. Cir. 1988) (holding appeal premature); United States v. Kirk, No. 88-5660 (6th Cir. Aug. 1, 1988) (LEXIS, 1988 U.S. App. LEXIS 10244) (dismissing pre-conviction appeal); Johns, 858 F.2d at 159 (dismissing appeal); United States v. Daniels, 848 F.2d 758, 760 (7th Cir. 1988) (holding appeal premature); Midland Asphalt, 840 F.2d at 1045-46 (dismissing appeal); Umited States v. LaRouche Campaign, 829 F.2d 250, 253 (1st Cir. 1987) (dismissing appeal); United States v. Taylor, 798 F.2d 1337, 1340 (10th Cir. 1986) (dismissing appeal). But see United States v. Benjamin, 812 F.2d 548, 553 (9th Cir. 1987) (permittimg appeal). 
defendant must show actual prejudice. In the course of the pretrial proceedings in Mechanik, the grand jury issued one indictment and then a second, superseding indictment for violations of federal drug enforcement laws and for conspiracy. ${ }^{30}$ The Rule 6(d) violation occurred during the government's presentation of additional evidence for the superseding indictment: two federal Drug Enforcement Administration agents testified simultaneously, taking turns and occasionally interrupting one another to indicate the criminal count applicable to the other's testimony. ${ }^{31}$ The district court took the defendants' motion to dismiss under advisement. 32 After the petit jury returned a guilty verdict, the court found that, the agents' testimony aside, adequate evidence supported the superseding indictment; it therefore held that the agents' testimony did not prejudice the defendants and denied the defendants' motion. ${ }^{33}$ The United States Court of Appeals for the Fourth Circuit reversed, however, reasoning that to require prejudice would undermine Rule 6(d)'s assurance "that grand jurors, sitting without the direct supervision of a judge, are not subject to undue influence that may come with the presence of an unauthorized person." 34

In reversing the Fourth Circuit, the Supreme Court suggested that a defendant could never show sufficient prejudice to prevail in light of a subsequent conviction. ${ }^{35}$ Writing for a divided court, then-Associate Justice Rehnquist noted that Rule 6(d) "protects against the danger that a defendant will be required to defend against a charge for which there is no probable cause to believe him guilty." 36 Conceding that the Rule 6(d) violation could have influenced the grand jury's decision to indict, ${ }^{37}$ Justice Rehnquist focused on the relevance of that influence in light of the petit jury's verdict:

[T]he ... subsequent guilty verdict means not only that there was probable cause to believe that the defendants were guilty as charged,

30. See United States v. Lill, 511 F. Supp. 50, 52-53 (S.D. W. Va. 1980), aff'd in part and rev'd in part sub nom. United States v. Mechanik, 735 F.2d 136 (4th Cir. 1984), aff'd en banc per curiam, 756 F.2d 994 (4th Cir. 1985), aff'd in part and rev'd in part, 475 U.S. 66 (1986).

31. See id.

32. Id. at 51 .

33. Id. at 58-61. The district court thus refused to apply the pre-Mechanik "per se" rule of dismissal employed in several circuits. This rule conclusively presumed prejudice to the target in cases involving violations of, for example, Rule 6(d), even though such violations had had an uncertain impact on grand jury deliberations. See id. at 58 (collecting cases involving Rule 6(d) violations); 2 W. LAFAVE \& J. IsRAEL, supra note $24, \S 15.6$ (discussing Rule $6($ d) violations).

34. Mechanik, 735 F.2d at 139.

35. Mechanik, 475 U.S. at 71 ("[R]eversal of a conviction after a trial free from reversible error cannot restore to the defendant whatever benefit might have accrued to him from a trial on an indictment returned in conformity with Rule 6(d).").

36. Id. at 70 .

37. Id. 
but also that they are in fact guilty as charged beyond a reasonable doubt. ... [A]ny error in the grand jury proceeding connected with the charging decision was harmless beyond a reasonable doubt. ${ }^{38}$

In other words, the guilty verdict "demonstrate[d] a fortiori" that the grand jury had probable cause to issue its indictment. ${ }^{39}$

Justice Rehnquist did note that, since Rule 6(d) guards against tainted grand jury charging decisions, indictments arguably should be compared to the evidence presented to the grand jury, rather than to the petit jury at trial..$^{40} \mathrm{He}$ dismissed this argument easily, however, stating that a reversal would not restore Rule 6(d) protections to a defendant who has already endured trial: "He will already have suffered whatever inconvenience, expense, and opprobrium that a proper indictinent may have spared him. In courtroom proceedings as elsewhere, 'the moving finger writes; and, having writ, moves on." "41

In the balance of his opinion, Justice Rehnquist focused on the costs of reversing convictions. If a convicted defendant were reindicted, a new trial would further tax the participants. Moreover, the "[p]assage of time, erosion of memory, and dispersion of witnesses" might fatally weaken an otherwise strong case; as a result, society might lose its "right to punish admitted offenders." 42 Even if the second trial resulted in conviction, that result would not adequately serve society's interest in swift justice or the ends of deterrence and rehabilitation. ${ }^{43}$ Justice Rehnquist thus concluded that, whatever the merits of reversing a conviction after an unfair trial, when grand jury error has no influence on a petit jury's verdict, the costs of reversal outweigh the benefits. ${ }^{44}$

\section{Id.}

39. Id. at 67.

40. Id. at 71 .

41. Id.

42. Id. at 72 (quoting Engle v. Isaac, 456 U.S. 107, 127-28 (1982)).

43. Id. (quoting United States v. Hasting, 461 U.S. 499,509 (1983)).

44. Id. at 72-73. The Court stated that its decision would not prevent courts from setting aside convictions without a showing of prejudice in cases of racially biased selection of grand jurors. See $i d$. at 70 n.1. Justice Rehnquist noted that in Vasquez v. Hillery, 474 U.S. 254 (1986), a case decided in the same year, setting aside a conviction as a result of such discrimination was "compelled by precedent directly applicable to the special problem of racial discrimination." Mechanik, 475 U.S. at 70 n.1. As he explained Vasquez,

racial discrimination in the selection of grand jurors is so pernicious, and other remedies so impractical, that the remedy of automatic reversal was necessary as a prophylactic means of deterring grand jury discrimination in the future, and that one could presume that a discriminatorily selected grand jury would treat defendants of excluded races unfairly.

Id. (citations omitted).

Rehnquist then distinguished Mechanik from Vasquez:

We think that these considerations have little force outside the context of racial discrimination in the composition of the grand jury. No long line of precedent requires the setting aside of a conviction based on a rule violation in the antecedent grand jury proceedings, 
Although the appellate courts have applied Mechanik to dismiss a variety of postconviction appeals involving prosecutorial grand jury misconduct, they have reached disparate conclusions about the scope and impact of the Mechanik decision. ${ }^{45}$ Some have heard interlocutory appeals of asserted grand jury errors, reasoning that Mechanik forecloses effective postconviction review. ${ }^{46}$ Others have asserted that Mechanik, despite its absolute language, does not require a postconviction finding of harmless error in cases involving especially flagrant, widespread, or egregious prosecutorial misconduct. ${ }^{47}$

In its aftermath, then, Mechanik raises two interrelated questions. First, if the decision forecloses postconviction appellate review of motions to dismiss for prosecutorial misconduct, can a defendant challenge a district court's denial of such a motion before a verdict? Second, after Mechanik, can an appellate court review denials of motions that allege especially egregious prosecutorial misconduct? The most thorough judicial treatment of these questions has occurred in the context of pre-judgment appeals in which a conviction has not yet triggered Mechanik's harmless error rule. ${ }^{48}$ The next part reviews the federal final judgment rule and collateral order doctrine in the criminal context and considers how these doctrines affect the validity of recent judicial treatment of interlocutory appeals involving prosecutorial grand jury misconduct.

\section{INTERLOCUTORY APPEALS OF GRAND JURY ERROR AFTER MECHANIK}

\section{A. The Final Judgment Rule and the Collateral Order Doctrine.}

Under the final judgment rule, codified at 28 U.S.C. section 1291, federal appellate courts have jurisdiction to review only the final decisions of district courts. ${ }^{49}$ As the "dominant rule" governing federal appellate procedure, ${ }^{50}$ the final judgment rule reinforces the authority of district courts, curbs undue harassment of opponents, and promotes the

and the societal interest in deterring this sort of error does not rise to the level of the interest in deterring racial discrimination. Id.

45. See infra notes $106-31$ and accompanying text.

46. See, e.g., United States v. Benjamin, 812 F.2d 548 (9th Cir. 1987) (allowing interlocutory appeal).

47. See, e.g., United States v. Johns, 858 F.2d 154 (3d Cir. 1988) (dismissing interlocutory appeal because claim of egregious prosecutorial misconduct would be reviewable after conviction).

48. See infra notes $65-90$ and accompanying text.

49. 28 U.S.C. § 1291 (1982).

50. Flanagan v. United States, 465 U.S. 259, 270 (1984) (quoting DiBella v. United States, 369 U.S. 121, 126 (1962)); see also Cobbledick v. United States, 309 U.S. 323, 324 (1940) ("Finality as a condition of review is an historic characteristic of federal appellate procedure."), quoted with approval in Flanagan, 465 U.S. at 263. 
efficient administration of justice. ${ }^{51}$

The rule, however, is not absolute. In Cohen v. Beneficial Industrial Loan Corp., a 1949 civil case, the Supreme Court gave the rule a "practical rather than a technical construction." 52 As the Court noted, 28 U.S.C. section 1292, which confers jurisdiction over interlocutory appeals in certain civil contexts, ${ }^{53}$ "indicate[s Congress's] purpose to allow appeals from orders other than final judgments when they have a final and irreparable effect on the rights of the parties." 54 In recognizing this exception to the final judgment rule, the Court created the federal collateral order doctrine.55 As restated in Coopers \& Lybrand v. Livesay, the doctrine imposes three requirements: to qualify as an immediately reviewable collateral order, a district court ruling must "conclusively determine the disputed question[,] . . . resolve an important issue completely separate from the merits of the action[,] and ... be effectively unreviewable on appeal from a final judgment."56

Despite its "practical" application of the final judgment rule in civil cases, the Court has strictly adhered to the policy of finality in the criminal context. ${ }^{57}$ In this context, "final judgment" generally means convic-

51. Flanagan, 465 U.S. at 263-64; see also Cobbledick, 309 U.S. at 326 (for purposes of appellate procedure, finality "is the means for achieving a healthy legal system").

52. 337 U.S. 541,546 (1949).

53. 28 U.S.C. $\$ 1292$ (1982 \& Supp. IV 1986). The section confers interlocutory jurisdiction in matters related to injunctions, receiverships, and admiralty cases. Id. $\S 1292(\mathrm{a})$. It also provides jurisdiction over other civil orders when a district court "shall be of the opinion that such order involves a controlling question of law as to which there is substantial ground for difference of opinion and that an immediate appeal ... may materially advance the ultimate termination of the litigation ...." Id. $\$ 1292(\mathrm{~b})$.

54. Cohen, 337 U.S. at 545.

55. The Cohen Court held that a district court's order refusing to apply a state security bond statute in a derivative action was immediately appealable because it was a "final disposition of a claimed right" entirely distinct from the cause of action. Id. at 546-47. The "Cohen doctrine," as originally formulated by the Court, allows interlocutory appeal from

that small class [of orders] which finally determine claims of right separable from, and collateral to, rights asserted in the action, too important to be denied review and too independent of the cause itself to require that appellate consideration be deferred until the whole case is adjudicated.

Id. at 546. Technically, the collateral order doctrine represents an expansion of, rather than an exception to, section 1291: the finality required by the section lies not in the termination of any part of an action, but in a district court's final determination that materially affects substantive rights. Collateral orders, however, are considered interlocutory rather than final. See 15 C. WRIGHT, A. Miller \& E. CoOper, Federal Practice and Procedure § 3911 (1976 \& Supp. 1988) (discussing collateral order doctrine).

56. 437 U.S. 463, 468 (1978); accord Stringfellow v. Concerned Neighbors in Action, 480 U.S. 370, 375 (1987) (quoting Coopers \& Lybrand, 437 U.S. at 468 (footnote omitted)); Flanagan v. United States, 465 U.S. 259, 265 (1984) (stating same three conditions); Firestone Tire \& Rubber Co. v. Risjord, 449 U.S. 368, 375 (1981) (same).

57. Flanagan, 465 U.S. at 264 (pretrial disqualification of defense counsel not immediately appealable). 
tion and sentencing. ${ }^{58}$ The Court has emphasized that this policy promotes society's strong interest in swift resolution of criminal prosecutions, as well as society's interest in judicial economy. ${ }^{59}$ Accordingly, it has allowed appeals before conviction and sentencing in only three types of criminal cases: those involving bail reduction requests, ${ }^{60}$ double jeopardy claims, ${ }^{61}$ and speech or debate clause claims. ${ }^{62}$

Following this approach, appellate courts have generally dismissed interlocutory appeals of motions to dismiss for prosecutorial grand jury misconduct. The courts reasoned that if they allowed pre-judgment review of such claims, the collateral order doctrine would swallow the final judgment rule. Moreover, at least before Mechanik, orders denying motions to dismiss did not satisfy the third criterion of the collateral order

58. Id. at 263 (citing Berman v. United States, 302 U.S. 211, 212 (1937)).

59. Id. at 264-65. Interrupting a criminal prosecution increases the likelihood that evidence will deteriorate, adds to the cost of pretrial detention, prolongs the period during which an accused, at large pending a verdict, might commit other crimes, and increases the delay in healing the "wound on the community" that crime has inflicted. Id.; see also id. at 264 ("[T] here is a societal interest in providing a speedy trial which exists separate from, and at times in opposition to, the interests of the accused." (quoting Barker v. Wingo, 407 U.S. 514, 519 (1972))); cf. United States v. MacDonald, 435 U.S. 850, 863 (1978) (order denying motion to dismiss made on speedy trial grounds not immediately reviewable).

In Cobbledick v. United States, 309 U.S. 323, 325-26 (1940), Justice Frankfurter succinctly stated the Court's view on interlocutory appeals in criminal eases:

[Thel considerations of policy [reflected in the final judgment rule] are especially compelling in the administration of criminal justice. . . An accused is entitled to scrupulous observance of constitutional safeguards. But encouragement of delay is fatal to the vindication of the criminal law. Bearing the discomfiture and cost of a prosecution for crime even by an innocent person is one of the painful obligations of citizenship. The correctness of a trial court's rejection even of a constitutional claim made by the accused in the process of prosecution must await his conviction before its reconsideration by an appellate tribunal.

60. See Stack v. Boyle, 342 U.S. 1, 6 (1951).

61. See Abney v. United States, 431 U.S. 651, 659 (1977).

62. See Helstoski v. Meanor, 442 U.S. 500, 508 (1979).

In Flanagan, the Supreme Court recently reviewed the availability of interlocutory appeal in criminal cases, holding that any appeal of a pretrial order disqualifying criminal defendants' joint counsel must await conviction. 465 U.S. at 270 . The Court distinguished the ease from those in which it had allowed immediate review by noting that such an appeal based on either the federal due process clause, U.S. CoNST, amend. V, or the assistance-of-counsel clause, id. amend. VI, is "in no danger of becoming moot upon conviction and sentence." 465 U.S. at 266-67. Moreover, unlike an appeal based on double jeopardy or on the speech or debate clause, the right to due process or to counsel does not involve a "right not to be tried" in the first instance, but rather, "like virtually all rights of criminal defendants, merely a right not to be convicted in certain circumstances." Id. at 267 (emphasis added). The right to counsel is in this respect analogous to the right to a speedy trial or to freedom from vindictive prosecution. Id. at 267 (citing United States v. MacDonald, 435 U.S. 850,860 (1978) (speedy trial right protected by postconviction review and hence not immediately appealable)); United States v. Hollywood Motor Car Co., 458 U.S. 263, 268 (1982) (similar disposition of vindictive prosecution claim)). The Flanagan Court declined to apply the collateral order doctrine morc liberally than it had in the past, noting that "[t]he costs of such expansion are great, and the potential rewards are small"; moreover, interruptions of trial in criminal cases "exact[ ] a presumptively prohibitive price." Id. at 269 (citations omitted). 
doctrine; the courts could effectively review prosecutorial misconduct after a conviction, dismissing the tainted indictment then if necessary. ${ }^{63}$ After Mechanik, however, the prospect that a conviction might now render grand jury orders "effectively unreviewable" on appeal has forced some courts to reconsider the reviewability of such orders prior to conviction and sentencing.

\section{B. Interlocutory Appeal of Grand Jury Error After Mechanik.}

Dissenting vigorously in Mechanik, Justice Marshall remarked that the Court's holding might cause denials of Rule 6(d) motions to dismiss to fall within the collateral order doctrine. Assuming a district court's order denying such a motion is separable from the merits of the prosecution, as well as final, Mechanik would supply the third element of the doctrine by rendering the order "wholly unreviewable." 64 Courts that construe Mechanik as foreclosing postconviction review of orders denying motions to dismiss for grand jury error have nevertheless disagreed whether such motions are appealable under the collateral order doctrine. The Ninth Circuit applies Mechanik broadly and, using an analysis similar to that suggested by Justice Marshall, ${ }^{65}$ now allows interlocutory appeal of these motions. Other courts have held interlocutory appeals to be inappropriate despite the unavailability of subsequent review under Mechanik. ${ }^{66}$

63. See, e.g., United States v. Bird, 709 F.2d 388, 391 \& n.17 (5th Cir. 1983) (denial of motions to dismiss for prosecutorial misconduct held not appealable under collateral order doctrine); United States v. Bendis, 681 F.2d 561, 569 (9th Cir. 1981) (motion to dismiss because of grand jury irregularities held not immediately appealable before trial), cert. denied, 459 U.S. 973 (1982); United States v. Litman, 661 F.2d 17, 19 (3d Cir. 1981) (denial of motion to dismiss not immediately appealable since "collateral finality rule" not satisfied), cert. denied, 454 U.S. 1150 (1982); United States v. Linton, 655 F.2d 930, 932 (9th Cir. 1980) (appeal alleging prosecutorial misconduct dismissed), cert. denied, 451 U.S. 912 (1981); In re Grand Jury Proceedings (Johanson), 632 F.2d 1033, 1039 (3d Cir. 1980) (criteria for immediate appealability not met); United States v. Garner, 632 F.2d 758, 766 (9th Cir. 1980) (interlocutory appeal denied since collateral order exception not met and grand jury proceedings reviewable and remediable after conviction), cert. denied, 450 U.S. 923 (1981); see also 15 C. Wright, A. Miller \& E. CoOPER, supra note 55, § 3918 (Supp. 1988) (discussing requirement of finality in criminal appeals). But cf. In re November 1979 Grand Jury, 616 F.2d 1021, 1024-25 (7th Cir. 1980) (appeal from denial of evidentiary hearing allowed because meetings between current prosecutor and former prosecutor whose conduct had resulted in dismissal of prior indictment in same case presented danger of "unique" injury not remediable by future review).

64. Mechanik, 475 U.S. at 81 n.1 (Marshall, J., dissenting).

65. In its decisions involving interlocutory appeal of grand jury orders, the Ninth Circuit has not explicitly referred to Justice Marshall's Mechanik dissent. See United States v. Dederich, 825 F.2d 1317 (9th Cir. 1987); United States v. Benjamin, 812 F.2d 548 (9th Cir. 1987).

66. See United States v. Poindexter, 859 F.2d 216, $221-22$ (D.C. Cir. 1988); United States v. Kirk, No. 88-5660 (6th Cir. Aug. 1, 1988) (LEXIS, 1988 U.S. App. LEXIS 10244); United States v. Daniels, 848 F.2d 758, 760 (7th Cir. 1988); United States v. LaRouche Campaign, 829 F.2d 250, 254 (1st Cir. 1987); cf. United States v. Taylor, 798 F.2d 1337, 1339 (10th Cir. 1986) (No "additional 
The following discussion addresses the Ninth Circuit's position and then considers whether orders denying motions to dismiss for grand jury irregularities are separable from the merits of a criminal action, as the second part of the collateral order test requires. It then considers whether, even if such orders are separable, pre-verdict review comports with the Supreme Court's strict application of the final judgment rule in criminal cases.

In United States v. Benjamin, ${ }^{67}$ the Ninth Circuit stated its view that Mechanik renders virtually all error involving prosecutorial grand jury misconduct harmless. In that case, the district court had denied the defendants' motion to dismiss their indictment for a violation of Rule 6(e)(2)'s secrecy provisions. ${ }^{68}$ The Ninth Circuit allowed an appeal under the collateral order doctrine. 69

The court of appeals found the trial court's denial conclusive, separate from the merits of the action, and, under Mechanik's application of the harmless error rule, unreviewable after conviction. The court thus held that the denial fell within the Cohen collateral order exception to the finality requirement. ${ }^{70}$ The court also based its conclusion on the fact that if it denied interlocutory review, the defendants would

wholly fail to benefit from the protections Rule 6(e) imposes on the constitutionally-mandated grand jury process. ... We cannot believe that Congress and the Supreme Court intended such ineffectiveness for the Rule. An interlocutory appeal will prevent that untoward result, and $\S 1291$ is to be given a "practical rather than a technical

exception to the final judgment rule has arisen from Mechanik, like Athena from the head of Zeus.").

Several courts have skirted the issue of whether unreviewability under Mechanik would allow interlocutory appeal of grand jury error, by interpreting the Supreme Court's decision as affecting only allegations of "technical" error or by exercising their supervisory powers. See infra notes 10658 and accompanying text.

67. 812 F.2d at 548 .

68. Id. at 550. The Rule provides:

(2) General Rule of Secrecy. A grand juror, an interpreter, a stenographer, an operator of a recording device, a typist who transcribes recorded testimony, an attorney for the government, or any person to whom disclosure is made under paragraph (3)(A)(ii) of this subdivision shall not disclose matters occurring before the grand jury, except as otherwise provided for in these rules. No obligation of secrecy may be imposed on any person except in accordance with this rule. A knowing violation of Rule 6 may be punished as a contempt of court.

FED. R. CRIM. P. 6(e)(2). The Benjamin defendants alleged that the prosecution had caused disclosure of grand jury records to a government witness who was involved in a civil action against the defendants. Apparently, during his participation in the grand jury proceedings, the witness had amended his civil complaint to include allegations similar to those in the indictment that the grand jury subsequently returned. The prosecution then induced the district court to release grand jury materials to the witness, without advising the court of the existence of the civil suit. Benjamin, 812 F.2d at 549-50.

69. Benjamin, 812 F.2d at 553 .

70. Id. 
construction."71

In another Ninth Circuit case, United States v. Dederich, 72 which also involved an interlocutory appeal from a district court order in the Benjamin trial, the government based its opposition to the appeal on $\mathrm{Co}$ hen's requirement of separability. The government argued that the logic of Mechanik " 'inextricably link[s]' analysis of the grand jury's probable cause determination to the sufficiency of evidence at trial."73 The court conceded that in the context of a postconviction review, Mechanik would require consideration of a jury verdict. It asserted, however, that prosecutorial grand jury misconduct does not truly relate to the merits of a criminal case and that "[f]or purposes of the collateral order doctrine's second requirement, it is enough that a decision by this court on the present appeal will have no effect on the trial court's determination of guilt or innocence under the present or any superseding indictment."74 The court also found that under Mechanik, the error would be unreviewable after conviction, as in Benjamin, and denied the government's motion to dismiss.

In light of Mechanik, then, the Ninth Circuit has allowed immediate appeal from orders denying motions to dismiss indictments for prosecutorial misconduct. ${ }^{75}$ By doing so, the court has avoided Mechanik's insulation of prosecutorial conduct before grand juries from postconviction review. Cohen's requirement of separability, however, might demand more rigorous analysis than the Ninth Circuit has conducted. Moreover, other courts have rejected both Benjamin and Deder$i c h$, classifying the Ninth Circuit decisions as impermissible applications of the collateral order doctrine in the criminal context. ${ }^{76}$

Cohen's requirement of separability from the merits prevents "piecemeal review of 'steps toward final judgment" "that will ultimately merge in a court's final disposition of a case. ${ }^{77}$ A grand jury's determination of

71. Id. at 553-54 (footnotes omitted) (quoting Cohen v. Beneficial Indus. Loan Corp., 337 U.S. $541,546(1949))$.

72. 825 F.2d 1317 (9th Cir. 1987).

73. Id. at $\mathbf{1 3 2 0}$ (quoting Government Motion to Dismiss Appeal for Lack of Jurisdiction at 8).

74. Id.

75. Cf. United States v. Tobias, 836 F.2d 449, 452 (9th Cir. 1988) ("In order to challenge the denial of his motion ... [defendant] should have sought interlocutory review rather than appealing after his conviction." (citing Benjamin)), cert. denied, 108 S. Ct. 1299 (1988).

76. See infra notes 82-90 and accompanying text.

77. Van Cauwenberghe v. Biard, 108 S. Ct. 1945, 1952 (1988) (quoting Moses H. Cone Memorial Hosp. v. Mercury Constr. Corp., 460 U.S. 1, 12 (1983)) (denial of motion to dismiss civil complaint for forum non conveniens not separate enough from merits of action to fall within collateral order doctrine). 
probable cause seems just such a step, ${ }^{78}$ especially since Mechanik subordinates that determination to the trial jury's verdict. In addition, the Supreme Court has recently required a showing of actual prejudice before district courts may dismiss indictments for grand jury irregularities. ${ }^{79}$ As the Court has also observed, if a motion to dismiss requires a showing of prejudice, then a court cannot fairly assess the merits of a movant's allegations without knowing "the substance of the prosecution's and defendant's cases." 80 Thus, an order denying such a motion will not be sufficiently separate from the merits of the case to fall within the collateral order doctrine. ${ }^{81}$ The appellate courts, however, have largely ignored Cohen's second requirement in the context of interlocutory appeals alleging grand jury error, focusing instead on the propriety of allowing such appeals at all.

The United States Court of Appeals for the First Circuit was the first to consider the Ninth Circuit's view of Mechanik, along with the effect of Mechanik itself on pre-conviction appeals of grand jury error. In United States v. LaRouche Campaign, the defendants had moved to dismiss an indictment for various prosecutorial abuses before the grand jury. ${ }^{82}$ The district court dismissed the motion. ${ }^{83}$ On appeal, the defendants asserted that their "right to be tried only upon charges brought by an unbiased, informed grand jury" would be irretrievably lost without interlocutory review; therefore, they argued, the trial court's ruling fell within the collateral order doctrine. ${ }^{84}$ The defendants advanced two lines of reasoning to support this assertion: if the alleged error fell within the ambit of Mechanik, the order would be unreviewable after convic-

78. Brief for Respondent at 20-21, Midland Asphalt Corp. v. United States, No. 87-1905 (U.S. argued Jan. 17, 1989).

79. Bank of Nova Scotia v. United States, 108 S. Ct. 2369 (1988); see infra notes $142-49$ and accompanying text.

80. Flanagan v. United States, 465 U.S. 259, 268-69 (1984).

81. Id. (disqualification of counsel in criminal trial not immediately appealable); see also Richardson-Merrell Inc. v. Koller, 472 U.S. 424, 438-39 (1985) (Flanagan's prejudice/separability analysis applies to disqualifications of counsel in civil cases).

82. 829 F.2d 250 (1st Cir. 1987). The defendants alleged in part:

that the grand jury was used to investigate a pending indictment; that exculpatory evidence had been withheld from the grand jury; that the prosecutor had asked questions before the grand jury implying wrongdoing without any basis . . . t that ... the prosecutor had accused a witness of lying [within the hearing of the grand jury]; that the indicting grand jury may have been presented with excessive hearsay [and] misleading summaries of earlier grand jury testimony[;] ... that the government had violated Fed.R.Cr.P. 6(e)(2)'s secrecy provisions by disclosing impounded material to the press and public ... [; and that ] the government had engaged in a persistent and pervasive pattern of grand jury abuse designed to compromise and undermine the impartiality of the grand jury in violation of the Fifth Amendment.

Id.

83. Id. at 252.

84. Id. 
tion; alternatively, if Mechanik did not apply, the order was nevertheless immediately appealable because post-trial review would come too late to preserve their fifth amendment "right not to stand trial unless grand jury proceedings are free of irregularities." 85

The LaRouche Campaign court quickly disposed of the defendants' fifth amendment argument. As the court indicated, the defendants failed to present support for the existence of such a "right not to be tried"; moreover, before Mechanik, the courts had conclusively rejected such arguments. ${ }^{86}$ Turning to the possibility that Mechanik would foreclose postconviction review, the court considered several aspects of the collateral order doctrine: its requirement that the right at issue be "important," the Supreme Court's strict application of the doctrine in the criminal context, and the societal costs of piecemeal adjudication. ${ }^{87}$ Focusing on the requirement of importance, the court stated that "if the defect (and its effect) in the grand jury proceeding is not significant enough to warrant relief after conviction, we doubt that the alleged right invaded by the defect is 'important' enough, within the ineaning of Cohen v. Beneficial Industrial Loan Corp., . . . to call for an interlocutory appeal." 88 The court concluded that safeguards other than judicial review are available to check prosecutorial misconduct and therefore dismissed the interlocutory appeal. ${ }^{89}$ The Sixth, Seventh, and District of Columbia Circuits have reached similar conclusions. 90

The historical treatment of the final judgment rule and the collateral order doctrine in criminal contexts supports the First Circuit's approach. The Supreme Court's recent reemphasis of the strictness of the finality doctrine in crimmal cases ${ }^{91}$ suggests that defendants seeking interlocutory review must claim either a "right not to be tried" equal in magnitude to the rights conferred by the double jeopardy and speech or debate clauses, or another right important enough to outweigh society's interest

85. Id.

86. Id. (citing United States v. Garner, 632 F.2d 758, $765-66$ (9th Cir. 1980), cert. denied, 450 U.S. 923 (1981)). But cf. United States v. Dederich, 825 F.2d 1317, 1321 n.7 (9th Cir. 1987) (Garner consistent with allowing interlocutory appeal after Mechanik).

87. LaRouche Campaign, 829 F.2d at 254.

88. Id. (citation omitted).

89. Id.

90. See United States v. Poindexter, 859 F.2d 216, 221 (D.C. Cir. 1988) (expressly adopting LaRouche Campaign court's position); United States v. Kirk, No. 88-5660 (6th Cir. Aug. 1, 1988) (LEXIS, 1988 U.S. App. LEXIS 10244) (citing LaRouche Campaign as additional support in holding that interlocutory appeals in criminal proceedings are "expressly" limited to appeals from denials of motions to dismiss on double jeopardy and bail reduction grounds); United States v. Daniels, 848 F.2d 758, 760 (7th Cir. 1988) (adopting view similar to LaRouche Campaign court's).

91. See Flanagan v. United States, 465 U.S. 259, 264 (1984); see also supra note 62 (discussing Flanagan). 
"in the prompt administration of justice."92 Although the LaRouche Campaign court and like-minded courts have summarily dismissed assertions of a right not to be tried, ${ }^{93}$ some commentators have asserted that such a right does exist. ${ }^{94}$ In light of the grand jury's historical function as a shield of the innocent as well as a sword of the state, ${ }^{95}$ this view has more than a "superficial attraction." 96 Yet, the Supreme Court's traditional treatment of grand jury irregularities does not support an inference from the grand jury clause of a robust right not to be tried upon an indictment "biased" by prosecutorial misconduct.

In Costello v. United States, for example, the Court severely limited the scope of appellate review of challenges to the sufficiency of grand jury evidence. ${ }^{97}$ Since grand juries historically have not been subject to demanding evidentiary rules, an "indictment returned by a legally constituted and unbiased grand jury, ... if valid on its face, is enough to call for trial of the charge on the merits." 98 In order to avoid the implications of this strict language, some courts have found that prosecutorial misconduct "biases" a grand jury such that its indictment is tainted even under Costello. ${ }^{99}$ As Professor Beale and Deputy Solicitor General Bryson note, however, the Costello Court, in mentioning bias as a factor, most probably meant bias in the selection of grand jury members. 100 Moreover, the Court's recent decision in Bank of Nova Scotia v. United States, discussed more fully below, ${ }^{101}$ drew a sharp distinction between grand jury errors such as invidious discrimination in the selection of grand jurors and other, arguably less suspect, errors-a distinction that suggests that most errors are not "fundamental."102 Apparently, therefore, defects in grand jury proceedings do not implicate any right not to

92. Mechanik, 475 U.S. at 70 (quoting United States v. Hasting, 461 U.S. 499, 509 (1983)); see supra notes 42-44, 58-62, and accompanying text.

93. See Daniels, 848 F.2d at 760; LaRouche Campaign, 829 F.2d at 252.

94. See, e.g., Curran \& Margolius, supra note 26, at 29, col. 1.

95. See supra notes 3-5 and accompanying text.

96. United States v. Garner, 632 F.2d 758, 763 (9th Cir. 1980), cert. denied, 450 U.S. 923 (1981).

97. 350 U.S. 359 (1956) (indictment based entirely on hearsay nevertheless valid); see $2 \mathrm{~S}$. BEALE \& W. BRYSON, supra note $2, \S 10: 20$.

98. Costello, 350 U.S. at 363; cf. United States v. Calandra, 414 U.S. 338 (1974) (upholding indictment based on illegally obtained evidence).

99. See supra note 90.

100. 2 S. Beale \& W. BRyson, supra note 2, § 10:22. Costello cites Pierre v. Louisiana, 306 -U.S. 354 (1939), a case mandating dismissal of indictments for violations of the equal protection clause, when referring to the requirement of an unbiased grand jury. 350 U.S. at 363 n.7.

101. See infra notes 138-44 and accompanying text.

102. 108 S. Ct. 2369, 2375 (1988); See Brief for Respondent at 23 \& n.14, Midland Asphalt Corp. v. United States, No. 87-1905 (U.S. argued Jan. 17, 1989). 
be tried. 103

Finally, allowing interlocutory appeal from denials of motions to dismiss grand jury indictments would cause the collateral order exception to swallow the final judgment rule. Most defendants could make at least a colorable claim of bias. ${ }^{104}$ Thus, in light of the Supreme Court's repeated emphasis on society's interest in speedy resolution of criminal prosecutions, the collateral order doctrine seems an inappropriate means of securing review of prosecutorial misconduct before federal grand juries. ${ }^{105}$

\section{THE SCOPE OF MECHANIK}

The courts of appeals have disagreed about Mechanik's effect on claims that a prosecutor has committed more than "technical" transgressions. Several courts have asserted that instances of prosecutorial misconduct may be so flagrant or unfair that Mechanik would not require a postconviction finding of harmless error. ${ }^{106}$ For example, in United

103. United States v. Daniels, 848 F.2d 758, 760 (7th Cir. 1988). As the Daniels court noted, "Hollywood Motor Car holds that objections to the procuring of an indictment may not be raised by interlocutory appeal." Id. In drawing this conclusion, however, the Seventh Circuit ignored the Hollywood Motor Car opinion's emphasis on the availability of review after conviction. See United States v. Hollywood Motor Car Co., 458 U.S. 263, 270 (1982).

104. E.g., United States v. Garner, 632 F.2d 758, 766 (9th Cir. 1980) ("In every criminal prosecution a defendant could make a motion to dismiss because of the type of evidence presented to the grand jury . . . ."), cert. denied, 450 U.S. 923 (1981); see also United States v. MacDonald, 435 U.S. 850,862 (1978) (denying interlocutory appeal of denial of motion to dismiss for violation of speedy trial clause).

105. See Daniels, 848 F.2d at 760 ("Multiple appeals produce leaden-footed justice and divert the time of courts from more pressing questions raised by other parties."); United States v. LaRouche Campaign, 829 F.2d 250, 254 (9th Cir. 1987):

[S]ome of the very considerations underlying the Court's conclusion in Mechanik that the societal costs of retrial after conviction were too substantial to justify setting aside a verdict because of a Rule $6(\mathrm{~d})$ violation in the grand jury proceedings are the same considerations influencing the strictness with which the final judgment rule is applied in the criminal context.

By contrast, allegations of double jeopardy and speech or debate clause violations, which may support an interlocutory appeal, seem to be self-limiting: only defendants previously put in jeopardy and Members of Congress have standing to allege such claims. See Garner, 632 F.2d at 766 (distinguishing claims of prosecutorial grand jury misconduct from double jeopardy claims).

106. See, e.g., United States v. Johns, 858 F.2d 154, 159 (3d Cir. 1988) (dictum) ("In our view, Mechanik was not intended to preclude the postconviction review of assertions of errors that implicate more than merely technical deficiencies."); United States v. Bucci, 839 F.2d 825, 832 (1st Cir. 1988) (dictum) ("[W]e recognize that there could be allegations of grand jury abuse so troubling as to warrant an assessment, under Mechanik, of whether the 'societal interest in deterring the type of abuses alleged' outweighed the 'societal costs of retrial' . . ." (quoting LaRouche Campaign, 829 F.2d at 253)); United States v. Taylor, 798 F.2d 1337, 1340 (10th Cir. 1986) ("We perceive that the Court has drawn a distinction between a defendant's right not to stand accused except upon a finding of probable cause and a broader right to fundamental faimess throughout the criminal process ...."); cf. Porter v. Wainwright, 805 F.2d 930, 942 (11th Cir. 1986) ("[W] expressly do not decide whether prosecutorial misconduct in a grand jury setting is always rendered harmless by a petit 
States v. Taylor, the Tenth Circuit concluded that Mechanik does not encompass prosecutorial misconduct that undermines the "fundamental fairness" of the criminal system. ${ }^{107}$ The Taylor defendants sought preconviction review of alleged grand jury error, arguing that Mechanik's harmless error rule rendered the district court's denial of their motion to dismiss unreviewable after a conviction and thus brought that ruling within the collateral order doctrine. ${ }^{108}$ The court of appeals disagreed, asserting that the Supreme Court's decision in Mechanik "was carefully crafted along very narrow lines" and that it would not foreclose effective review after conviction in the case at hand. ${ }^{109}$

The Taylor court characterized the Rule 6(d) violation at issue in Mechanik as "at worst, . . . technical, and, at most, . . . affect[ing] only the grand jury's determination of probable cause"; thus, the violation did not raise the question whether the prosecution was fundamentally unfair. ${ }^{110}$ The court asserted that the Mechanik Court did not hold that a Rule 6 violation or other misconduct affecting the fundamental fairness of pretrial criminal proceedings was nonjusticiable after conviction. ${ }^{111}$ It concluded that the violations alleged by the Taylor defendants were not merely technical, but implicated the defendants' right to fundamental fairness in the criminal process. Since the issues went beyond the alleged violations' impact on the grand jury's determination of probable cause, a petit jury conviction would not render them moot; the court thus held interlocutory appeal inappropriate. ${ }^{112}$

jury's guilty verdict ...."), cert. denied, 107 S. Ct. 3195, 107 S. Ct. 3196 (1987). But see United States v. Fountain, 840 F.2d 509, 515 (7th Cir.) ("The [Mechanik] Court's reasoning ... does not depend upon the nature of the rule at hand ...."), cert. denied, 109 S. Ct. 533 (1988); United States v. Dederich, 825 F.2d 1317, 1320 \& n.6 (9th Cir. 1987) (Under Mechanik, flagrant misconduct that deceives a grand jury or compromises its independent judgment, and thus "would have justified the district court in dismissing the indictment before trial, would go wholly unremedied if the district court itself erred in denying dismissal." (footnote omitted) (quoting United States v. Benjamin, 812 F.2d 548, 553-54 (9th Cir. 1987)); 2 W. LAFAVE \& J. ISRAEL, supra note 24, § 15.5(h) (Supp. 1988) (arguing that Mechanik's analysis would apply to indictment challenges based on most prosecutorial abuses, including persistent or flagrant misconduct).

107. 798 F.2d 1337, 1338 (10th Cir. 1986). The alleged misconduct included:

(1) invasion of the defense camp by the prosecution in violation of the attorney-client privilege and defendants' Sixth Amendment rights; (2) abuse of the grand jury through prosecutorial misconduct in the form of the prosecution's failure to present exculpatory evidence and its biasing of the grand jury with inadmissible, inflammatory, and prejudicial evidence; and (3) improper utilization of state officers in the grand jury investigation.

Id.

108. See supra note 64 and accompanying text.

109. 798 F.2d at 1340 .

110. Id.

111. Id.

112. Id. 
In United States v. Johns, the Third Circuit adopted the Taylor court's reasoning and dismissed a similar interlocutory appeal of grand jury error. ${ }^{113}$ The First Circuit, too, has asserted that "there could be allegations of grand jury abuse so troubling as to warrant an assessment, under Mechanik, of whether the 'societal interest in deterring the type of abuses alleged' outweighed the 'societal costs of retrial.' "114

These courts, in asserting that indictments may be dismissed after conviction, even in light of Mechanik, seem to be asserting their "supervisory power" over the grand jury process. Although courts do not always explicitly state the basis for such postconviction review, their concern with preserving fundamental fairness and pumshing flagrant abuses (always with a view to deterrence) suggests an ain to police, or supervise, the integrity of the criminal process, rather than to redress deprivations of rights in individual cases. ${ }^{115}$ As argued below, this approach clashes both with the Mechanik decision and with the limitations on supervisory power ariiculated in recent Supreme Court decisions.

\section{A. Mechanik's Inflexible Analysis.}

The Mechanik Court's harmless error analysis and cost/benefit approach strongly suggest that its rule would apply even to allegations of serious misconduct. ${ }^{116}$ Justice Rehnquist's logic seems to address all prosecutorial misconduct, regardless of its magnitude. As long as inisconduct is "sufficiently aimed at the grand jury's charging process," 117

113. 858 F.2d 154, 159 (3d Cir. 1988).

114. United States v. Bucci, 839 F.2d 825, 832 (1st Cir.) (quoting United States v. LaRouche Campaign, 829 F.2d 250, 253 (1st Cir. 1987)), cert. denied, 109 S. Ct. 117 (1988).

The First Circuit will not undertake such a balancing inquiry in all cases, however. In Bucci, which involved a postconviction appeal, the appellant contested a grand jury's indictment, claiming that it was based on unfairly prejudicial evidence and that the government had not disclosed that one witness had committed perjury. Id. at 831. The court concluded that these allegations of abuse warranted no assessment of competing interests to determine whether Mechanik's harmless error rule should apply. Id. at 832 .

115. See, e.g., Johns, 858 F.2d at 159-60 ("The grand jury abuses alleged ... are different from the violation that was at issue in Mechanik .... [They raise] the question of whether the government violated the defendant's 'right to fundamental fairness' ... [and] implicate issues that go to 'the fundamental fairness of the criminal proceedings.' " (citations omitted)); United States v. Vest, 842 F.2d 1319, 1334 (1st Cir.) ("Even under Mechanik, the federal courts still have the responsibility to supervise the government's use of its prosecutorial powers."), cert. denied, $109 \mathrm{~S}$. Ct. 489 (1988); Bucci, 839 F.2d at 832 ("[W]e recognize that there could be allegations of grand jury abuse so troubling as to warrant an assessment, under Mechanik, of whether the 'societal interest in deterring the type of abuse alleged' outweighed the 'societal costs of retrial' ...."); United States v. Taylor, 798 F.2d 1337, 1340 (10th Cir. 1986) ("[Defendants] are asserting that their right to fundamental fairness has been adversely affected by the ... acts of which they complain. ... [T] hese issues can be raised upon appeal if the defendants are convicted.").

116. 2 W. LAFAVE \& J. ISRAEL, supra note $24, \S 15.5$ (h) (Supp. 1988).

117. United States v. Benjamin, 812 F.2d 548, 553 (9th Cir. 1987). 
and unless the error involves allegations of racial discrimination, ${ }^{118}$ Mechanik will apply.

The Mechanik majority focused on the grand jury error at issue and its relevance in light of the petit jury's verdict. ${ }^{119}$ In its view, deprivation of a fair trial process might justify reversal, "[b]ut the balance of interest tips decidedly the other way when an error has had no effect on the outcome of the trial." 120 Thus, conviction conclusively determines the outcome of the balancing analysis, completely overshadowing the issue of pretrial fundamental fairness. Apparently, a court hearing a postconviction appeal may now consider "fairness" only with respect to the trial itself. ${ }^{121}$

The Ninth Circuit, in United States v. Benjamin, ${ }^{122}$ has also broadly construed Mechanik. The court reasoned that any difference between the Rule 6(d) violation in Mechanik and the Rule 6(e) violation in Benjamin would not foreclose application of Mechanik's harmless error rule after conviction. The defendants' argument was "primarily one of taint, or an improper effect on the grand jury's decision to indict"; 123 under Mechanik, according to the Ninth Circuit, a guilty verdict erases any prejudice from an improper grand jury charging decision. ${ }^{124}$

The court applied the same reasoning in United States v. Deder-

118. Mechanik, 475 U.S. at $70 \mathrm{n} .1$ (racial discrimination is so pernicious that it makes automatic reversal necessary) (citing Vasquez v. Hillery, 474 U.S. 254 (1986)); see also 2 W. LAFAVE \& J. ISRAEL, supra note $24, \S 15.5(\mathrm{~h})$ (Supp. 1988) (noting that harmless error analysis does not apply to racial discrimination in grand jury selection).

119. See Mechanik, 475 U.S. at 70; see also id. at 76 (O'Connor, J., concurring) ("[T]he Court shifts the focus of the harmless error analysis [after a verdict is returned] from an examination of the violation's effect on the indictment to an assessment of the violation's effect on the trial verdict ....").

120. Id. at 72 .

121. See 2 W. LAFAvE \& J. ISRAEI, supra note $24, \S 15.5(\mathrm{~h})$, at 81 (Supp. 1988) (footnotes omitted):

The dismissal of an indictment in a postconviction setting conceivably could be distinguished when the trial of [sic] appellate court rested its ruling on the need to use its supervisory power to control flagrant or persistent abuses of prosecutorial authority before the grand jury. ... [But] the language of the Mechanik opinion ... suggest[s] that such a distinction would not be appealing to the Supreme Court .... Also, although the Mechanik dissent clearly pointed out that the majority's ruling would leave enforcement of Rule 6(d) to the "unreviewable largesse of the district court," the majority viewed that consequence as an insufficient justification for adopting a contrary rule. It noted simply that the "societal costs of retrial after a jury verdict of guilty are far too substantial to justify setting aside a verdict" on the basis of "an error [that] has had no effect on the outcome of the trial."

122. 812 F.2d 548 (9th Cir. 1987).

123. Id. at 552. But see United States v. Midland Asphalt Corp., 840 F.2d 1040, 1046 (2d Cir.) (Rule 6(e) protects interests very different from those that Rule 6(d) protects; thus, convictions will not render Rule 6(e) violations harmless), cert. granted, 108 S. Ct. 2869 (1988) (No. 87-1905).

124. 812 F.2d at 553. 
$i c h,{ }^{125}$ even though that case involved allegations of misconduct more serious than the Rule 6(e) violation at issue in Benjamin. According to the Dederich defendants, the prosecutor had repeatedly forced witnesses to assert their fifth amendment privilege, harassed witnesses associated with the defense, failed to disclose evidence relating to witnesses' credibility, presented false evidence, and misused the grand jury's subpoena power. ${ }^{126}$ These egregious abuses notwithstanding, the court of appeals concluded that Mechanik would apply to the defendants' claims, and, consequently, that conviction would moot those claims. ${ }^{127}$ In the court's view, even flagrant prosecutorial conduct that deceived a grand jury or undermined its independence and "would have justified the district court in dismissing the indictment before trial, would go wholly unremedied if the district court itself erred in denying dismissal."128

The Seventh Circuit has adopted a similarly broad view of Mechanik in the context of postconviction appeals. In United States $v$. Fountain, because of the defendant's conviction at trial, the court held irrelevant his allegations that the prosecutor presented evidence of a recantation later denied and hearsay evidence and failed to present exculpatory evidence. ${ }^{129}$ The court suggested that reversing the conviction would have been "silly": the guilty verdict had removed the defendant from the class of persons (i.e., the innocent) harmed by improperly obtained indictments, and he could have been reindicted "in a trice" given the trial record's availability to a new grand jury. ${ }^{130}$ The Fountain court conceded that the Rule 6(d) violation in Mechanik was a "technicality," but observed that the decision's rationale applies to any rule designed to protect the innocent from indictment: "we know, as surely as courts 'know' anything, that the convicted defendant is not a member of the class of beneficiaries of [such a] rule."131

Under the Seventh and Ninth Circuits' reasoning, Mechanik rejects the overturning of convictions as a means of deterring prosecutorial misconduct. All types of misconduct that prejudice or bias a grand jury pose the same danger as the Rule 6(d) violation in Mechanik: "that a defendant will be required to defend against a charge for which there is no probable cause to believe him guilty."132 Mechanik thus seems to require

125. 825 F.2d 1317 (9th Cir. 1987).

126. Id. at 1319 .

127. Id. at 1320 .

128. Id. (footnote omitted) (quoting Benjamin, 812 F.2d at 553-54).

129. 840 F.2d 509, 514 (7th Cir.), cert. denied, 109 S. Ct. 533 (1988).

130. Id.

131. Id. at 515. As Judge Easterbrook, writing for the unanimous panel, also noted: "Most important legal rules, even constitutional ones, may be enforced only by their beneficiaries." Id.

132. Mechanik, 475 U.S. at 70. 
a finding of harmless error in virtually all postconviction appeals that allege prosecutorial grand jury misconduct. ${ }^{133}$ As the following section discusses, other Supreme Court cases seem to support this position by limiting the appellate courts' ability to "supervise" prosecutors' conduct before grand juries.

\section{B. Circumventing Harmless Error Analysis Through the Use of Supervisory Power.}

Supervisory power ${ }^{134}$ provides courts with an attractive means for avoiding the strictures that the Supreme Court has imposed on constitutional challenges to grand jury indictments. ${ }^{135}$ Prior to Mechanik, some

133. As a witness before the House Judiciary Committee's Subcommittee on Criminal Justice has testified, "Justice Rehnquist's opinion contains dictum indicating that the ban on post-verdict relief is nearly absolute, extending to any error in the grand jury proceeding connected with the charging decision.' " Hearings on H.R. 1407, supra note 28, at 344 (statement of Henry Scott Wallace, Legislative Director, National Association of Criminal Defense Lawyers); see also 2 W. LAFAVE \& J. IsRAEL, supra note 24, $\S 15.5(\mathrm{~h})$ (Supp. 1988) (commenting on absolute nature of Mechanik analysis).

Justice Rehnquist reserved an exception to Mechanik's harmless error rule: cases involving racial discrimination in the selection of a grand jury or venire. The rationale behind this exception, however, does not apply to any other kind of irregularity in grand jury proceedings. See Mechanik, 475 U.S. at 70 n.l; see also supra note 44.

134. The doctrine of supervisory power originated in McNabb v. United States, 318 U.S. 332 (1943), in which the Supreme Court asserted a "supervisory authority over the administration of criminal justice in the federal courts" that "implie[d] the duty of establishing and maintaining civilized standards of procedure and evidence." Id. at 341, 340. " "[G]uided by considerations of justice' ... federal courts may, within limits, formulate procedural rules not specifically required by the Constitution or the Congress." United States v. Hasting, 461 U.S. 499, 505 (1983) (quoting $M c^{-}$ $N a b b, 318$ U.S. at 341). The supervisory power exists "to implement a remedy for violation of recognized rights; to preserve judicial integrity by ensuring that a conviction rests on appropriate considerations validly before the jury; and, finally, as a remedy desigued to deter illegal conduct." Id. (citations omitted).

135. 2 S. BeAle \& W. BRyson, supra note 2, § 10:22(b); Beale, Reeonsidering Supervisory Power in Criminal Cases: Constitutional and Statutory Limits on the Authority of the Federal Courts, 84 CoLUM. L. REv. 1433, 1458-59 (1984). The fifth amendment guarantees the right to be tried only upon indictment by a grand jury. Stirone v. United States, 361 U.S. 212, $217-18$ (1960). Arguably, therefore, a court may invalidate an indictment on constitutional grounds if the misconduct at issue violates the defendant's rights under the due process or grand jury clauses. See, e.g., United States v. Schell, 775 F.2d 559, 565 (4th Cir. 1985) (appearance before grand jury by United States Attorney, who had previously represented suspects "with respect to the very same criminal activity which led to the indictment that he ultimately helped to prosecute," violates due process), cert. denied, 475 U.S. 1098 (1986); United States v. Sears, Roebuck \& Co., 719 F.2d 1386, 1391 n.7 (9th Cir. 1983) (recognizing grand jury clause as basis for dismissal), cert. denied, 465 U.S. 1079 (1984); United States v. Pino, 708 F.2d 523, 530 (10th Cir. 1983) (due process clause as basis for dismissal); United States v. Hinton, 543 F.2d 1002, 1010 (2d Cir.) (indictment on basis of immunized testimony violated defendant's rights under due process and grand jury clauses), cert. denied, 429 U.S. 980 (1976).

In Costello v. United States, 350 U.S. 359 (1956), and United States v. Calandra, 414 U.S. 338 (1974), the Supreme Court limited the scope of such constitutional review of grand jury matters. See supra notes 97-98 and accompanying text. In Costello, the Court implied that the grand jury should remain independent of the courts as well as the executive. See Costello, 350 U.S. at 362 ("There is 
lower federal courts used their supervisory power to dismiss indictments in an effort to safeguard grand juries' independence and impartiality from prosecutorial misconduct. ${ }^{136}$ These courts divided, however, over the question whether dismissal requires a showing of actual prejudice to the defendant. ${ }^{137}$

every reason to believe that our constitutional grand jury was intended to operate substantially like its English progenitor[,] ... [which] acquired an independence ... free from control by the Crown or judges.") As Beale and Bryson note, however, there is little basis for excepting supervisory power decisions from these constitutional limitations. 2 S. BEALE \& W. BRYSON, supra note 2, $\S 10: 22$.

Moreover, some constitutional errors are subject to the harmless error doctrine. Chapman v. California, 386 U.S. 18, 22 (1967); see also Hasting, 461 U.S. at 510-12 (prosecutor's closing argument, commenting on defendants' silence concerning crimes, was rendered harmless beyond reasonable doubt in light of "compelling case of guilt"); 3 W. LAFAVE \& J. IsRAEL, supra note 24, $\S 26.6(\mathrm{c})$-(e). Others may infringe "rights so basic to a fair trial that their infraction can never be treated as harmless error." Chapman, 386 U.S. at 23. See generally 3 W. LAFAVE \& J. IsRAEL, supra note $24, \S 26.6(\mathrm{~d})$ (analysis of conflict between harmless error and "automatic reversal" doctrines). Dictum in the Bank of Nova Scotia decision suggests, however, that only misconduct as serious as racial or gender discrimination justifies such a presumption. Bank of Nova Scotia $\mathbf{v}$. United States, 108 S. Ct. 2369, 2375 (1988); see also 2 W. LAFAVE \& J. ISRAEL, supra note 24, $\S 15.5$ (h) (Supp. 1988) (reading Mechanik in this way). Constitutional error subject to the harmless error doctrine will be deemed harmless if it is "clear beyond a reasonable doubt that the [trial] jury would have returned a verdict of guilty" had the error not occurred. Hasting, 461 U.S. at 510-11; Chapman, 386 U.S. at 23-24; see also 3 W. LAFAVE \& J. ISRAEL, supra note 24, $\$ 26.6$ (c) (describing cases).

136. See, e.g., United States v. Talbot, 825 F.2d 991, 998 n.5 (6th Cir. 1987) (citing cases in which courts dismissed indictments under supervisory powers or on fifth amendment due process grounds), cert. denied, 108 S. Ct. 773 (1988); United States v. Hogan, 712 F.2d 757, 761 (2d Cir. 1983) (using supervisory power to preserve jury's independence by dismissing indictment); Pino, 708 F.2d at 530 (indictment may be dismissed for flagrant prosecutorial misconduct that infringes on grand jury's ability to exercise independent judgment); United States v. Serubo, 604 F.2d 807, 816 (3d Cir. 1979) (given potential for abuse in grand jury proceedings, courts will use supervisory power to regulate grand jury investigations); United States v. Estepa, 471 F.2d 1132, 1135-37 (2d Cir. 1972) (using supervisory power to dismiss indictment where hearsay misleadingly presented to grand jury).

Courts and commentators have disagreed on the propriety of using the courts' supervisory power to dismiss indictments because of misconduct. See 2 S. BEALE \& W. BRYSON, supra note 2, $\S 10: 22$ (b) (noting controversy over whether supervisory power has same limits as constitutionally based decisions and over requirement of prejudice to the defendant); B. GERSHMAN, supra note 10, $\S 2.2$ (b), at 2-8 to -9 (dismissals under supervisory power used to remedy prosecutorial misconduct, preserve integrity of grand jury, and deter similar misconduct in future); Note, supra note 10, at 1088-92 (discussing circuit courts' divergence on whether indictment may be dismissed because of prosecutorial misconduct in absence of grand jury prejudice). For a comprehensive critical discussion of the federal courts' supervisory powers in criminal cases, see Beale, supra note 135.

A fundamental problem with such dismissals is that lower courts' supervisory-powers-based regulation of prosecutorial conduct in the grand jury room appears to lack constitutional or statutory authority. See id. at 1491-94. A bill entitled the Grand Jury Procedural Protection Act of 1987, H.R. 100-3308, supra note 28 , would have provided a concrete source of authority for this sort of regulation. See supra note 28.

137. See 2 S. BEALE \& W. BRYSON, supra note $2, \S 10: 22 \& 91$ n.71. Specifically, courts disagreed whether prejudice is required in cases of persistent misconduct, 2 id. $\S 10: 22$, at 91 , or of statutory violations having an uncertain impact, such as the presence of unauthorized persons in the grand jury room, $c f$. United States v. Lill, 511 F. Supp. 50, 58-59 (S.D. W. Va. 1980) (collecting and distinguishing cases involving Rule 6(d) violations), aff'd in part and rev'd in part sub nom. 
The Supreme Court recently resolved this issue in Bank of Nova Scotia v. United States, holding that dismissal for grand jury error generally requires a finding of actual prejudice to the defendant. ${ }^{138}$ The district court in Bank of Nova Scotia had dismissed an indictment because the prosecutor's misconduct had destroyed the grand jury's independence. ${ }^{139}$ The district court had invoked its supervisory authority in order to unequivocally declare the seriousness of such misconduct and the court's refusal to tolerate it. ${ }^{140}$ The Supreme Court held, however, that courts may not avoid the harmless error rule by using supervisory power. ${ }^{141}$ According to the Court, indictments may be dismissed without specific determinations of prejudice only in cases that involve misconduct as fundamental as discrimination in the selection of grand jurors. ${ }^{142}$ Those cases represent not "isolated exceptions to the harmless error rule," but "ones in which the structural protections of the grand jury have been so compromised as to render the proceedings fundamentally unfair, allowing the presumption of prejudice."143

As the Bank of Nova Scotia Court carefully noted, it did not decide whether erosions of grand juries' independence or systematic abuse would justify district courts in dismissing indictments pursuant to their supervisory power. ${ }^{144}$ Even if the Court had decided that such misconduct justifies dismissal, that result would not have affected the harmless error analysis under Mechanik. In a postconviction appeal, whether the grand jury error at issue involves a pattern of abuse or is merely technical has no bearing on the actual prejudice that a defendant has suffered, assessed after his conviction by an untainted petit jury-the standard set by Justice Rehnquist in Mechanik. Although egregious misconduct might justify supervisory-power-based dismissal of an indictment at the trial level, conviction would nevertheless render such misconduct harmless at the appellate level.

Mechanik, 735 F.2d 136 (4th Cir. 1984), aff'd en banc per curiam, 756 F.2d 994 (4th Cir. 1985), aff'd in part and rev'd in part, 475 U.S. 66 (1986); 2 W. LAFAVE \& J. ISRAEL, supra note 24, § 15.6.

138. $108 \mathrm{~S}$. Ct. at 2373.

139. United States v. Kilpatrick, 594 F. Supp. 1324, 1353 (D. Colo. 1984), rev'd, 821 F.2d 1456 (10th Cir. 1987), aff'd sub nom. Bank of Nova Scotia, 108 S. Ct. at 2369. The misconduct included "numerous violations of Rule $6(\mathrm{~d})$ and (e), ... violations of 18 U.S.C. $\$ \S 6002$ and 6003, violations of the Fifth and Sixth Amendments ...., knowing presentation of misinformation to the grand juryand mistreatment of [grand jury] witnesses." Id.

140. Id. at 1352-53 (prosecutors denied grand jury ability to "undertake its essential mission"; dismissal of indictment is thus warranted).

141. Bank of Nova Scotia, 108 S. Ct. at 2374.

142. Id. at 2375 (citing Vasquez v. Hillery, 474 U.S. 254 (1986) (racial discrimination); Ballard v. United States, 329 U.S. 187 (1946) (exclusion of women)); see also Mechanik, 475 U.S. at 70 n.1, cited in Bank of Nova Scotia, 108 S. Ct. at 2375.

143. $108 \mathrm{~S}$. Ct. at 2375 (emphasis added).

144. Id. at 2376. 
One of the cases relied upon by the Bank of Nova Scotia Court dealt specifically with the limits of an appellate court's supervisory power in cases involving harmless error. In United States v. Hasting, the Supreme Court held that a federal court of appeals may not avoid a harmless error determination by relying on its supervisory power alone. ${ }^{145}$ Although the Seventh Circuit in Hasting did not state the basis for its holding, the Supreme Court assumed that the court had acted pursuant to its supervisory power and, as a result, reversed the circuit court's decision. ${ }^{146}$ As the Supreme Court stated, "the interests preserved by the doctrine of harmless error cannot be so lightly and casually ignored in order to chastise what the [appellate] court viewed as prosecutorial overreaching."147

Thus, a defendant who alleges grand jury error in his appeal from a valid conviction will have suffered no actual prejudice and thus will not be entitled to a reversal. In short, the process will ultimately have produced a correct result in that defendant's case. Unless the misconduct at issue involved something as serious as racial discrimination, reversal would disobey the dictates of Bank of Nova Scotia and Hasting, as well as the spirit of Mechanik. As the Mechanik Court concluded, when an untainted petit jury has found guilt beyond a reasonable doubt, the interests behind the harmless error rule outweigh any interests served by dismissal of an indictment. ${ }^{148}$ By reversing a conviction because of prosecutorial grand jury misconduct, a court of appeals would compromise the balance of interests that the Supreme Court has firmly established. This conclusion, combined with the circuit courts' inability to review claims of such misconduct on an interlocutory basis, means that the circuit courts have no direct role in checking prosecutorial misconduct or in protecting grand juries' independence.

145. 461 U.S. 499,505 (1983).

146. Id. at 505, 512 . The Supreme Court noted that the Seventh Circuit was concerned with the prosecutor's practice of commenting on defendants' silence at trial and inferred that the court, "notwithstanding the harmless nature of the error, ... acted in this case to discipline the prosecutor-and warn other prosecutors." Id. at 504.

147. Id. at 507. After examining the record, the Hasting Court found the alleged error "harmless beyond a reasonable doubt." Id. at 510,512 . The Court noted that the goals served by supervisory powers do not control in cases involving harmless error: reversal by supervisory power is an unnecessary remedy when a defendant would have been convicted anyway; moreover, concern for the integrity of the process "carries less weight" when an error is truly harmless, presumably because the process has ultimately yielded a correct result. Id. at 506. The Court also observed that deterrence through reversal is inappropriate when there are "more narrowly tailored" means to deter misconduct, such as "directing the District Court to order the prosecutor to show cause why he should not be disciplined, or by asking the Department of Justice to initiate a disciplinary proceeding against him... The Court also could have publicly chastised the prosecutor by identifying him in its opinion." Id. at 506 \& n.5 (citations omitted).

148. See supra notes $40-44$ and accompanying text. 
C. Errors Reviewable Even After Mechanik.

Even after Mechanik, however, appellate courts may still dismiss indictments and reverse convictions when prosecutorial misconduct results in either a facially invalid indictment ${ }^{149}$ or an unfair trial. ${ }^{150}$ For example, United States v. Midland Asphalt Corp., ${ }^{151}$ a case currently before the Supreme Court, involves misconduct that implicates the fairness of a trial, and thus illustrates the distinction between reviewable and effectively unreviewable grand jury error.

In Midland Asphalt, the Second Circuit dismissed an interlocutory appeal from a denial of a motion to dismiss for Rule 6(e) secrecy violations and other abuses. ${ }^{152}$ The court reasoned that, because Rule 6(e) protects interests essentially unrelated to findings of probable cause, Mechanik would not require a finding of harmless error after conviction, and the defendant's right to appellate review would remain. ${ }^{153}$ The court noted that the Rule's secrecy provisions protect society's important interest in concealing the identities of grand jury witnesses and targets. In addition, the Rule "safeguards the interests of society and of the defendant in receiving a fair trial" by restricting the pretrial disclosure of potentially prejudicial information. ${ }^{154}$ In light of Rule 6(e)'s purpose, the court concluded that, "unlike a violation of Rule 6(d), a violation of Rule 6 (e) is not rendered harmless simply because the defendant is convicted; at least in some instances, the more egregious the violation of Rule 6(e), the more likely it becomes that the petit jury will convict."15s

The Midland Asphalt court correctly suggested that conviction will not necessarily moot a Rule 6(e) violation that damages a defendant's interest in a fair trial. Prejudice resulting from grand jury error is to be measured by the petit jury verdict, and if that verdict is itself tainted, it cannot moot the grand jury error. ${ }^{156}$ However, the Midland Asphalt court inappropriately considered possible interests in grand jury secrecy, apart from protecting petit juries from inflammatory publicity. After

149. See United States v. Hooker, 841 F.2d 1225, 1232-33 (4th Cir. 1988) (en banc) (conviction did not render absence of essential element from indictment, which affected substantial right and was necessary to give district court jurisdiction, harmless).

150. United States v. Friedman, 854 F.2d 535, 583 (2d Cir. 1988) ("Mechanik by its terms does not bar reversal of a conviction when misconduct before the grand jury 'has deprived [the] defendant of a fair determination of the issue of guilt or innocence.' " (quoting Mechanik, 475 U.S. at 72)).

151. 840 F.2d 1040 (2d Cir.), cert. granted, 108 S. Ct. 2869 (1988) (No. 87-1905).

152. Id. at 1041 .

153. Id. at 1046.

154. Id.

155. Id.

156. See id.; United States v. Friedman, 854 F.2d 535, 583 (2d Cir. 1988). 
conviction, the interests at stake resemble those at stake in Mechanik, ${ }^{157}$ and, as the Court decided in that case, the balance favors preserving conviction. As long as a defendant receives a fair trial, he cannot demonstrate the prejudice required by Mechanik, and any erroneous refusal to dismiss an indictment tainted by secrecy violations becomes harmless. ${ }^{158}$

\section{The Practical Effect of MEChaNIK}

"To say that a question may evade appellate review is not to say that it will evade judicial review ...."159 Although Mechanik has eliminated the circuit courts' role in redressing grand jury error, under Bank of Nova Scotia a district court may still examine any grand jury error and dismiss an indictment " if it is established that the violation substantially influenced the grand jury's decision to indict,' or if there is 'grave doubt' that the decision to indict was free from the substantial influence of such violations."160 Reason exists, however, to question the effectiveness of district court review of prosecutorial misconduct before grand juries.

In his Mechanik dissent, Justice Marshall noted several practical impediments to full and fair review of motions to dismiss for grand jury violations. ${ }^{161}$ Grand jury secrecy requirements make it difficult for a defendant even to learn of improper prosecutorial conduct. ${ }^{162}$ Moreover, especially after Mechanik, district courts have an incentive to defer ruling on motions to dismiss until after a jury reaches a verdict: if the defendant is acquitted, the deferred motion becomes moot, and if he is

157. See Friedman, 854 F.2d at 582-83 (conviction moots effect of even pervasive or willful Rule 6(e) violations on grand jury's charging decision).

158. Since Midland, the Second Circuit seems to have recognized a distinction between allegations that pretrial secrecy violations tainted a grand jury and allegations that such violations tainted a petit jury. In Friedman, the court held that a conviction rendered an alleged Rule 6(e) violation harmless, even though there was no allegation that the violation improperly affected the trial jury. 854 F.2d at 583-84; see supra note 150 .

159. United States v. Daniels, 848 F.2d 758, 760 (7th Cir. 1988) (dismissing interlocutory appeal . of grand jury error).

160. Bank of Nova Scotia v. United States, 108 S. Ct. 2369, 2374 (1988) (quoting Mechanik, 475 U.S. at 78 (O'Connor, J., concurring)).

161. Mechanik, 475 U.S. at 80-81 (Marshall, J., dissenting).

162. Under FED. R. CR1M. P. 6(e)(3)(C)(ii), a court may grant a defendant's request for disclosure of grand jury records "upon a showing that grounds may exist for a motion to dismiss the indictment because of matters occurring before the grand jury." Courts, however, generally deny such requests. 2 S. BEALE \& W. BRYSON, supra note $2, \S 7: 11$. Although the necessary showing may often require knowledge of the materials that a defendant seeks to have disclosed, Mechanik, 475 U.S. at 80 (Marshall, J., dissenting), that possibility has not caused courts to view such motions favorably. 2 S. BEALE \& W. BRYson, supra note 2 , § 7:11. The Jencks Act, 18 U.S.C. $\$ 3500$ (1982), allows defendants access to a grand jury witness's statements after direct examination of that witness at trial. Id. §3500(b). See generally 2 S. BEALE \& W. BRYson, supra note 2, § 7:13. Such disclosure is necessarily limited, however, and occurs only after commencement of trial. See Mechanik, 475 U.S. at 80-81 (Marshall, J., dissenting). 
convicted, the grand jury error becomes harmless. 163 "The [Mechanik] Court's decision thus offers busy district judges a new and unique way to reduce their workload . . . ."164

Despite such practical obstacles to effective review by district courts, the circuit courts' power to reverse convictions arguably remains unnecessary because "nieans more narrowly tailored to deter objectionable prosecutorial conduct," such as contenipt sanctions, recommendations for professional discipline, and public chastisenient, are available. ${ }^{165}$. Courts and conimentators have noted, however, that

the constant flow of cases ... involving prosecutorial misconduct before petit juries demonstrates that judicial 'tongue clicking' and adjurations to the 'better practice' are likely to have little impact .... . And while professional disciplinary sanctions may be available, ... criminal defendants are unlikely to be in a position to initiate such proceedings, or to see that they are pressed to a successful conclusion. ${ }^{166}$

Thus, in the wake of Mechanik and Bank of Nova Scotia, judicial power to protect grand jury independence seenis ineffective and inadequate, and these cases' elimination of judicial safeguards against prosecutorial misconduct before grand juries is indeed troubling. However, reversing convictions to chastise and deter prosecutors visits high costs on society, especially when a guilty defendant has received all the protections of a fair trial. This dilenma suggests that protecting the grand jury's screening function requires measures other than reversals of convictions, at one extreme, and self-enforced prosecutorial guidelines, at the other. By insulating grand jury abuse from judicial intervention, the Supreme Court has left to Congress and the Departnient of Justice the task of tailoring appropriate inechanisms to safeguard the grand jury's traditional role as shield of the accused. ${ }^{167}$

163. See Mechanik, 475 U.S. at 77 (O'Connor, J., concurring); id. at 81 (Marshall, J., dissenting).

164. Id. at 81.

165. United States v. Hasting, 461 U.S. $499,506 \&$ n.5 (1983).

166. United States v. Serubo, 604 F.2d 807, 817-18 (3d Cir. 1979); see also United States v. Busher, 817 F.2d 1409, 1411-12 (9th Cir. 1987) (defendant cannot attack improperly obtained indictment on basis of prosecutor's nonadherence to United States Attorneys' Manual); UNIrEd STATES ATtORNEYs' MANUAL $\$ 1-1.100$ (1985) (manual 'is not intended to, does not, and may not be relied upon to create any rights, substantive or procedural, enforceable at law by any party in any matter civil or criminal"); cf. Hearings on H.R. 1407, supra note 28, at 313 (statement of Bernard S. Bailor, Vice-Chairperson, ABA White Collar Crime Committee) (Rule 6 contempt sanction not invoked in last 40 years).

167. Possible mechanisms might include establishment of a civil damages remedy or formal administrative complaint and review procedures. 


\section{CONCLUSION}

The Supreme Court's decision in United States v. Mechanik has both highlighted and exacerbated the problems of judicial review of prosecutorial grand jury misconduct. The terms of the Mechanik decision do not allow the lower courts to exclude errors involving "fundamental fairness" from the case's harmless error rule. Moreover, the Court has greatly restricted the appellate courts' "supervisory power" to reverse convictions as a means of deterring prosecutorial misconduct. Interlocutory review is not a viable alternative to postconviction review, given the Court's strict application of the collateral order doctrine in criminal cases. Such review would also encourage defendants to raise colorable but ultimately baseless clains of prosecutorial misconduct.

As those problems suggest, the courts cannot presently reconcile the competing interests of the grand jury clause and the harmless error rule. The Supreme Court's recent decisions in Mechanik and Bank of Nova Scotia have thus left the protection of grand jury procedures to the legislative and executive branches. 
